Pietrzak M.B., Wilk J., Metropolitan areas in central Poland and their impact on migration flows, „Ekonomia i Prawo. Economics and Law”, Polszakiewicz B., Boehlke J. (ed.), Vol. 13, No. 4/2014, pp. 545-558. DOI: http://dx.doi.org/10.12775/EiP.2014.039.

\author{
Michat Bernard Pietrzak*, Justyna Wilk**
}

\title{
METROPOLITAN AREAS IN CENTRAL POLAND AND THEIR IMPACT ON MIGRATION FLOWS ${ }^{\diamond}$
}

\author{
SUMMARY
}

The objective of the paper is to identify subregions (NUTS 3) of the central part of Poland pretending to metropolitan areas, as well as to study their impact on the domestic migration flows. Their social and economic situations in 2008 were determined on the basis of the composite measure values. Their participation in the domestic migration flows in the period 2008-2010, considering the directions, range and intensity of flows, was also examined.

Only Warsaw is the completely shaped metropolitan area in Poland. The city demonstrates the highest economic potential and therefore the strongest migration flows and dependences with other subregions. The cities of Poznań and Eódź and also the Bydgosko-toruński subregion can be recognized as developing metropolitan areas. These subregions represent significant economic centres; however migration flows related to them demonstrate mainly regional importance.

Keywords: metropolitan areas, migration flows, economic development, central Poland JEL Classification: J10, R11

* Michał Bernard Pietrzak, Nicolaus Copernicus University, Faculty of Economic Sciences and Management, Department of Econometrics and Statistics, ul. Gagarina 13A, 87-100 Toruń, phone: +48 5661146 06, e-mail: pietrzak@umk.pl (corresponding author).

** Justyna Wilk, Wrocław University of Economics, Faculty of Economics, Management and Tourism, The Chair of Econometrics and Computer Science, ul. Nowowiejska 3, 58-500 Jelenia Góra, phone: +48 757538 277, e-mail: Justyna.Wilk@ue.wroc.pl.

$\checkmark$ The project was co-financed by Nicolaus Copernicus University in Torun within a UMK research grant no. 1481-E. 


\section{INTRODUCTION}

Regional analyses conducted emphasise the importance of metropolitan areas as essential factors of social and economic development. That results from the fact that metropolitan areas are characterised by a significantly higher development dynamics if compared with non-metropolitan areas. Nowadays, metropolitan areas function as the world's most important economic, scientific, cultural, administrational, and political centres ${ }^{1}$. The development of innovation and creativity occurs within their areas and by means of diffusion they affect the whole of the adjacent region and, thereby, contribute to its development. Other benefits of metropolitan areas include a better developed transport infrastructure, diversified labour market, access to economic (technological parks, business incubators, centres of technology transfer, delivery institutions, financial institutions, etc.) and social (schools, universities, hospitals, cultural centres, etc.) infrastructure. Concentrating economic functions, work places and services rendered in metropolises affects an increase in ties between the central area and the nearest environment, and the whole region. It attracts not only capital and companies but also people, which results in more intense migration flows.

The subject literature indicates abundant definitions of metropolitan areas, their classifications, approaches, and methods of delimitation ${ }^{2}$. A metro-

${ }^{1}$ See P. Korcelli, Aglomeracje miejskie w systemach osadniczych. Wybrane hipotezy i perspektywy badawcze, „Przegląd Geograficzny”, Vol. 48/1976; W. Maik, Podstawy geografi miast, UMK, Torun 1997; A. Gawryszewski, P. Korcelli, E. Nowosielska, Funkcje metropolitalne Warszawy, IGiPZ PAN, Warszawa 1998; B. Jałowiecki, Spoteczna przestrzeń metropolii, Wydawnictwo Scholar, Warszawa 2000; G. Gorzelak, B. Jałowiecki, Europejskie granice - jedność czy podziat kontynentu?, „Studia Regionalne i Lokalne”, No. 2-3/2001; L. Kołodziejski (ed.), Koncepcja polityki przestrzennego zagospodarowania kraju, RCSS, Warszawa 2001; B. Jałowiecki, Zarzadzanie rozwojem aglomeracji miejskich, Wydawnictwo WSFiZ w Białymstoku, Białystok 2002; G. Gorzelak, M. Smętkowski, Metropolia i jej region w gospodarce informacyjnej, Wydawnictwo Naukowe Scholar, Warszawa 2005; T. Markowski, T. Marszał, Metropolie, obszary metropolitalne, metropolizacja. Problemy i pojęcia podstawowe, PAN, Komitet Przestrzennego Zagospodarowania Kraju, Warszawa 2006; D. Hołuj, A. Hołuj, Miasta metropolitalne jako bieguny rozwoju w gospodarce postindustrialnej, „Zeszyty Naukowe” WSE w Bochni, Vol. 4/2006; G. Gorzelak, A. Tucholska (ed.), Rozwoój, region, przestrzen, MRR-Euroreg, Warszawa 2007; B. Jałowiecki, Globalny świat metropolii, Wydawnictwo Naukowe Scholar, Warszawa 2007; I. Ładysz, Konkurencyjnośc obszarów metropolitalnych w Polsce (na przyktadzie wroctawskiego obszaru metropolitalnego), CeDeWu, Warszawa 2009; K. Heffner, Funkcje metropolitalne stolic województw Polski zachodniej, ekspertyza, Politechnika Opolska, UE w Katowicach, Opole 2011.

2 See B. Jałowiecki, Metropolie, Wydawnictwo WSFiZ w Białymstoku, Białystok 1999; T. Markowski, T. Marszał, op. cit.; J. Parysek, Metropolie: metropolitalne funkcje i struktury prze- 
politan area is usually defined as a settlement network with its centre represented by a strongly urbanized city (with over 500 thousand inhabitants) that is economically well developed. Poland's capital city - Warsaw, is an already shaped metropolitan area ${ }^{3}$, but there can be found other Polish cities that are currently strengthening their metropolitan functions. Determining them, however, requires redefining a metropolitan area for Polish realities. One of the crucial criteria that allows identifying metropolitan areas in Poland is the consideration of economic premises, as well as measuring the intensity and direction of migration flows.

The present paper attempts to identify metropolitan areas in the central part of Poland, as well as to study their impact on the domestic migration flows in the years 2008-2010, and also to analyse the scale and conditions of these processes. The paper is the continuation of the research conducted by its authors on the phenomenon of Poland's internal migration flows and its conditions ${ }^{4}$.

strzenne, [in:] Jażdżewska I. (ed.), Funkcje metropolitalne i ich rola w organizacji przestrzeni, Wydawnictwo UE, Łódź 2003; W. Maik, Pojęcie metropolii i problem badania funkcji metropolitalnych, [in:] Jażdżewska I. (ed.), Funkcje metropolitalne $i$ ich rola w organizacji przestrzeni, KGMiT UŁ, ŁTN Łódź 2003; M. Smętkowski, B. Jałowiecki, G. Gorzelak, Obszary metropolitalne w Polsce: problemy rozwojowe i delimitacja, „Raporty i analizy Euroreg”, CESRiL Euroreg, Warszawa 2009.

3 See E. Korcelli-Olejniczak, Berlin and Warsaw: in search of a new role in the European urban system, "Journal of Housing and the Built Environment", Vol. 22, No. 1/2007; A. Gawryszewski, P. Korcelli, E. Nowosielska, op. cit.

${ }^{4}$ See S. Matusik, M.B. Pietrzak, J. Wilk, Ekonomiczne-spoteczne uwarunkowania migracji wewnętrznych w Polsce w świetle metody drzew klasyfikacyjnych, „Studia Demograficzne”, No. 2(162)/2012; M.B. Pietrzak, N. Drzewoszewska, J. Wilk, The analysis of interregional migrations in Poland in the period of 2004-2010 using panel gravity model, „Dynamic Econometric Models”, Vol. 12/2012; M.B. Pietrzak, M. Żurek, S. Matusik, J. Wilk, Application of Structural Equation Modeling for analysing internal migration phenomena in Poland, „Przegląd Statystyczny", No. 4/2012, R. LIX; J. Wilk, M.B. Pietrzak, S. Matusik, Sytuacja spoteczno-gospodarcza jako determinanta migracji wewnętrznych w Polsce, [in:] K. Jajuga, M. Walesiak (ed.), Taksonomia 20-21. Klasyfikacja i analiza danych - teoria i zastosowania, PN UE we Wrocławiu, Wrocław 2013; J. Wilk, M.B. Pietrzak, Analiza migracji wewnętrznych w kontekście aspektów spoteczno-gospodarczych - podejście dwuetapowe, „Ekonometria”, Vol. 2(40)/2013; M.B. Pietrzak, J. Wilk, S. Matusik, Gravity model as a tool for internal migration analysis in Poland in 2004-2010, [in:] J. Pociecha (ed.), Quantitative Methods for Modelling and Forecasting Economic Processes, Wydawnictwo UE w Krakowie, Kraków 2013; M.B. Pietrzak, J. Wilk, Obszary metropolitalne Polski potudniowej a ruch migracyjny ludności, „Ekonomia i Prawo”, Vol. XII, No. 3/2013; M. B. Pietrzak, J. Wilk, M. Siekaniec, The impact of metropolitan areas on internal migrations in Poland. The case of southern regions, [in:] M. Papiez, S. Śmiech (ed.), Proceedings of the 7TH Professor Aleksander Zelias International Conference on Modelling and Forecasting of Socio-Economic Phenomena, 2013; M.B. Pietrzak, J. Wilk, M. Chrzanowska, Economic situation of eastern Poland and population migration movement, „Metody ilościowe w badaniach ekonomicznych”, Vol. XIV, No 2/2013; 


\section{POTENTIAL METROPOLITAN AREAS IN POLAND'S CENTRAL REGIONS}

Globalisation processes and Poland's accession to the European Union have resulted in the dynamic growth of the national economy. Such a situation has fostered the strengthening of the metropolitan functions of the country's largest cities and the competitiveness of the regions in which they are situated. Poland is characterised by a distinct territorial disparities in the level and rate of regional development. Significant economic disproportions are displayed by the regions situated in the central part of the country which comprise the Kujawsko-pomorskie, Wielkopolskie, Łódzkie, Mazowieckie, and Swiętokrzyskie regions. Due to their geographical location, the shape of the area, concentration of natural resources, regions situated in central Poland fulfil various (e.g., tourist, manufacturing, demographic base, etc.) functions. The regions can be defined as industrial, rendering services and agricultural.

The level of regional development including the economic potential is conditioned by economic profile, level of productiveness, entrepreneurship, inflow of foreign capital, predisposition to attract investments, companies' standing and the absorptiveness of the labour market ${ }^{5}$. The diversified level and rate of social and economic development in Poland impacts the formation of economically strong centres, both within regions and within the whole country, which display the features of metropolitan areas.

M. Biczkowski, M. Muszyńska, I. Müller-Frączek, M. B. Pietrzak, J. Wilk, The delimitation of bipolar metropolitan area within the kujawsko-pomorskie region, „Oeco-nomia Copernicana”, Vol. 5, No. 2/2014, p. 101-122; M.B. Pietrzak, J. Wilk, Odlegtośc ekonomiczna w modelowaniu zjawisk przestrzennych z wykorzystaniem modelu grawitacji, [in:] Jajuga K., Walesiak M. (ed.), Taksonomia 22. Klasyfikacja i analiza danych - teoria $i$ zastosowania, PN UE we Wrocławiu, Wrocław 2014; M.B. Pietrzak, J. Wilk, T. Kossowski, R. Bivand, The identification of spatial dependence in the analysis of regional economic development - join-count test application, [in:] Papiez M., Śmiech S. (ed.), Proceedings of the $8^{T H}$ Professor Aleksander Zelias International Conference on Modelling and Forecasting of Socio-Economic Phenomena, 2014.

5 See D. Strahl (ed.), Metody oceny rozwoju regionalnego, AE we Wrocławiu, Wrocław 2006; I. Müller-Frączek, M.B. Pietrzak, Wykorzystanie narzędzi statystyki przestrzennej do identyfikacji kluczowych ośrodków rozwoju województwa Kujawsko-Pomorskiego, „Acta Universitatis Nicolai Copernici. Ekonomia”, Vol. 38/2008; I. Müller-Frączek, M.B. Pietrzak, Analiza porównawcza rozwoju ekonomicznego województwa kujawsko-pomorskiego w latach 2003 i 2007 z wykorzystaniem narzędzi statystyki przestrzennej, „Acta Universitatis Nicolai Copernici. Ekonomia”, Vol. 39/2009; I. Müller-Frączek, M. B. Pietrzak, Potencjat ekonomiczny jako miara spoteczno-ekonomicznego rozwoju regionu na przyktadzie województwa kujawsko-pomorskiego, „Acta Universitatis Nicolai Copernici. Ekonomia”, Vol. 40/2009; B. Bal-Domańska, J. Wilk, Gospodarcze aspekty zrównoważonego rozwoju województw - wielowymiarowa analiza porównawcza, „Przegląd Statystyczny", Vol. 58, No. 3-4/2011, p. 320-322. 
The evaluation of the regional differentiation of the economic situation in central Poland was made on the level of subregions (NUTS 3). The analysis was conducted based on the set of diagnostic features contained in table 1 and the data on the situation in the subregions concerns the year 2008. That year was the time when Poland started to be affected by the world financial and economic crisis which manifested themselves in the economic slowdown. These processes were accompanied by a fall in the intensity of migration flows and the group of target migration regions was narrowed.

Table 1. Features describing economic potential of subregions

\begin{tabular}{|c|c|}
\hline DIAGNOSTIC VARIABLES & IMPACT DIRECTION \\
\hline Gross added value per employed person (in PLN) & Stimulant \\
\hline natural person conducting economic activity per 100 working-age persons (entity) & Stimulant \\
\hline $\begin{array}{l}\text { Share of commercial companies with foreign capital per } 100 \text { national economy entities } \\
\text { in the private sector (REGON - private sector) (\%) }\end{array}$ & Stimulant \\
\hline Investment outlays in enterprises per capita (PLN) & Stimulant \\
\hline $\begin{array}{l}\text { Share of persons employed in the service sector (market and non-market) in employed } \\
\text { persons (\%) }\end{array}$ & Stimulant \\
\hline Average monthly gross wages and salaries (PLN) & Stimulant \\
\hline Share of registered unemployed persons in working-age persons (\%) & Destimulant \\
\hline
\end{tabular}

Source: Own preparation.

The idea of the taxonomic development measure (TDM) was applied in the analysis. TDM allows analysing all features at the same time, as well as making synthetic evaluation of social and economic situation in subregions ${ }^{6}$. The construction process of the measure consisted of a few stages. Firstly, the preferences of variables were determined. Almost all of the variables function as stimulants. The exception is the unemployment rate which is a destimulant and its high values should be evaluated as negative. Next, the coordinates for the pattern object were determined. The upper pattern of development was taken as a reference point. The maximum values noted in 2008 were considered beneficial for stimulants and the minimum ones for destimulants. Then, the normalization of the changeable values was performed by means of the unitization with zero minimum. The character of the variables was unified by changing a destimulant into a stimulant and that was achieved by subtracting its value from 1 .

${ }^{6}$ See T. Grabiński, S. Wydymus, A. Zeliaś, Metody taksonomii numerycznej w modelowaniu zjawisk spoteczno-gospodarczych, PWN, Warszawa 1989. 
The distance between each object (subregion) and the pattern object was identified by means of Euclidean distance. Also, for each subregion the value of TDM was designated by means of Hellwig's method ${ }^{7}$. The interval of measure values was divided by means of the 3 -means ${ }^{8}$ method into four classes representing relatively high, moderate, low and very low levels of economic development. Results of the classification applied are shown in picture 1 .

The outcome of the research confirmed significant heterogeneity of the central area of Poland. The highest value of the measure within that area was noted in the city of Warsaw (0.987), and the lowest in the Sandomierskojędrzejowski subregion (0.119). Apart from Warsaw, the class of the highest level of development is also represented by the city of Poznań, the Warszawski zachodni subregion, and by the city of Łódź. Other examples of economically distinctive subregions include the independent Bydgosko-toruński subregion, the Poznański and Warszawski wschodni subregions.

Warsaw represents an already formed metropolis, however, while looking for subregions which display the features of metropolitan areas in central Poland, it is necessary to consider the intensity and directions of migration flows. More intense migration flows, particularly significant inflows and a positive net migration in the largest urban areas, indicate a growing position of the central area, if compared with the whole of the country.

\section{PARTICIPATION OF CENTRAL POLAND'S REGIONS IN DOMESTIC MIGRATION FLOWS}

A significant feature of migration flows is a delayed and stretched in time reaction to changes in the economic cycle. The fall in the intensity of internal migrations was observed not only in 2008 but also in the following years of the world crisis. Therefore, migration flows observed in the years 2008-2010 were considered throughout the whole period as aggregated values. In order to ensure the comparability of results, values were divided by the average population numbers in the $2008-2010$ period. The directions of interregional flows and the intensity of flows within subregions (intraregional flows) were analysed.

7 See Z. Hellwig, Zastosowanie metody taksonomicznej do typologicznego podziatu krajów ze względu na poziom rozwoju oraz zasoby i strukturę wykwalifikowanych kadr, „Przegląd Statystyczny", No. 4/1968.

${ }^{8}$ See E. Nowak, Metody taksonomiczne w klasyfikacji obiektów gospodarczych, PWE, Warszawa 1990. 
Picture 1. Economic situation in subregions of central Poland in 2008

\section{Level of Economic}

\section{Growth}

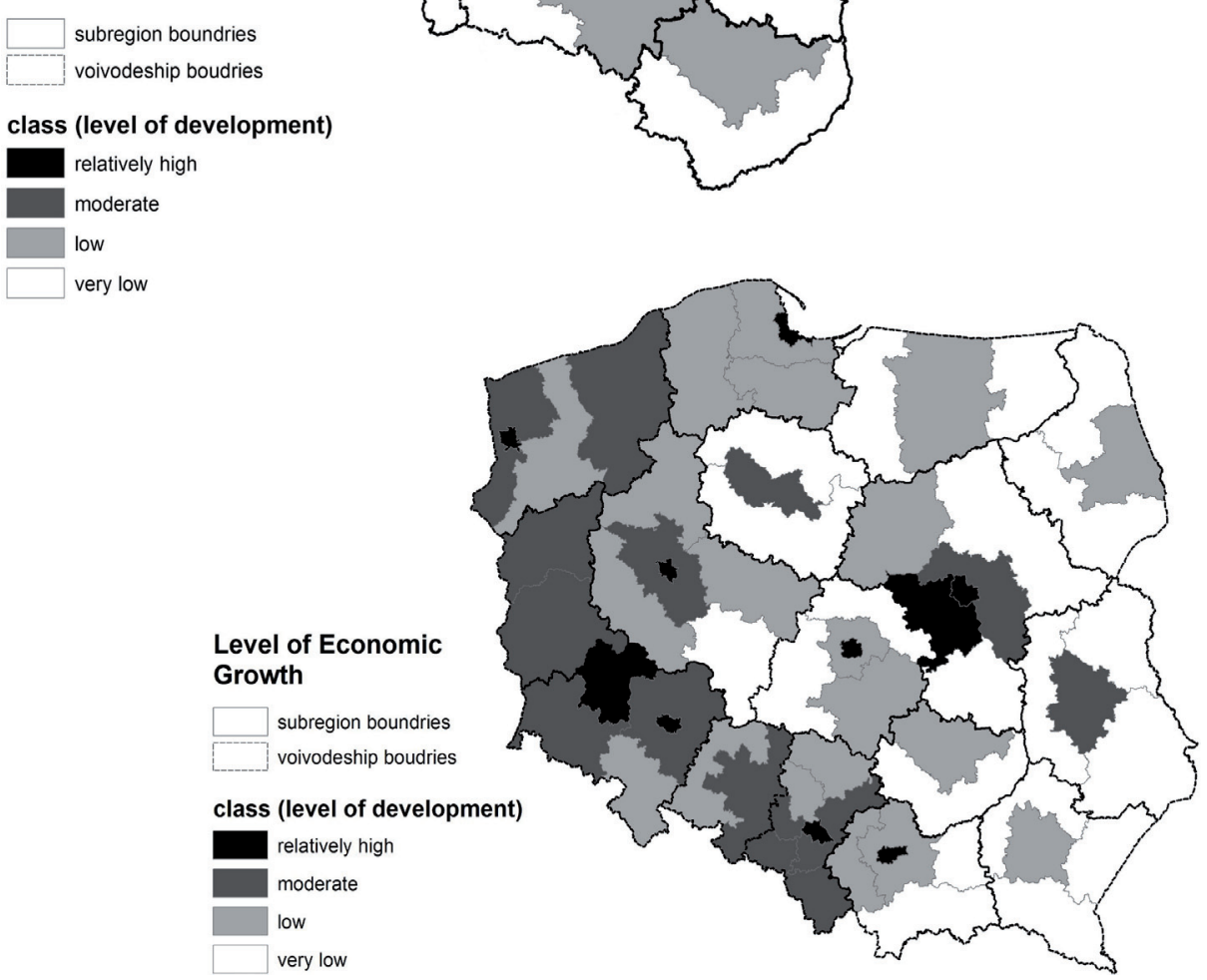

Source: Own preparation based on data BDL GUS.

The values of the intraregional flows ratio were divided into three classes equal in numbers. In the case of the interregional migration flows, with a view to maintaining clarity, five selected groups of flows were determined. Classes were created based on specific values of centiles. The class of 'very strong flows' was ascribed to $2 \%$ of the largest domestic migration flows (the values of the ratio were contained in the interval (C98, max)). The 'strong flows' class was set up for the interval (C96, C98). Also, a class of 'medium 
flows' was created and it was divided into three subclasses, i.e., 'medium flows (class 1)' for the interval (C94, C96), 'medium flows (class 2)' for the interval (C92, C94), and 'medium flows (class 3)' for the interval (C90, C92). Pictures 2 and 3 show the values of intraregional flows and the directions of strong and medium migration flows between subregions.

The strongest intraregional flows occur in the subregions of the Kujawsko-pomorskie and Wielkopolskie regions as well as in the western part of the Mazowieckie region. The subregions of the Eódzkie and Świętokrzyskie regions and of the eastern part of the Mazowieckie region display considerably lower intensity of intraregional migration flows.

In terms of migration flows the most hermetic region is the Kujawskopomorskie region. The directions of the largest interregional flows in this region indicate the occurrence of intense migration flows with the participation of the Bydgosko-toruński subregion. The subregion participates in the bilateral exchange of population with the Włocławski and Grudziądzki subregions. Strong migration flows crossing the borderlines of the Kujawsko-pomorskie region were identified merely by the Włocławski subregion. The situation in the Bydgosko-toruński region is peculiar since there are two leading centres there - the city of Bydgoszcz and the city of Torun. In the future a bipolar metropolitan area may be created in the region with its two core area centres.

Analysis of medium migration flows indicates essential relations holding between the Bydgosko-toruński subregion and the subregions of the adjacent regions, as well as between Warsaw, Poznań and the Gdański and Trójmiejski subregions (the Pomorskie region). It may be stated then that the Bydgoskotoruński subregion impacts the whole of the country. The strong migration flows with the participation of the Bydgosko-toruński subregion result from its good economic situation and prove the development of the relations that are typical of metropolitan areas.

The strong economic position of the Wielkopolskie region translates into more intense migration inflows of people from the neighbouring regions (the Lubuskie, Pomorskie and Kujawsko-pomorskie regions) to the region. However, the most intense migration flows can be observed between the subregions of the Wielkopolskie region. Strong bilateral migration flows can be observed between the city of Poznan and the Poznański subregion that surrounds it. The strong economic position of Poznań causes significant flows between it and the remaining subregions of the Wielkopolskie region, as well as bilateral migration flows with the participation of the Poznański subregion and its neighbouring subregions. 
Picture 2. The intensity of migration flows within subregions in Poland ${ }^{9}$ and of strong flows between subregions
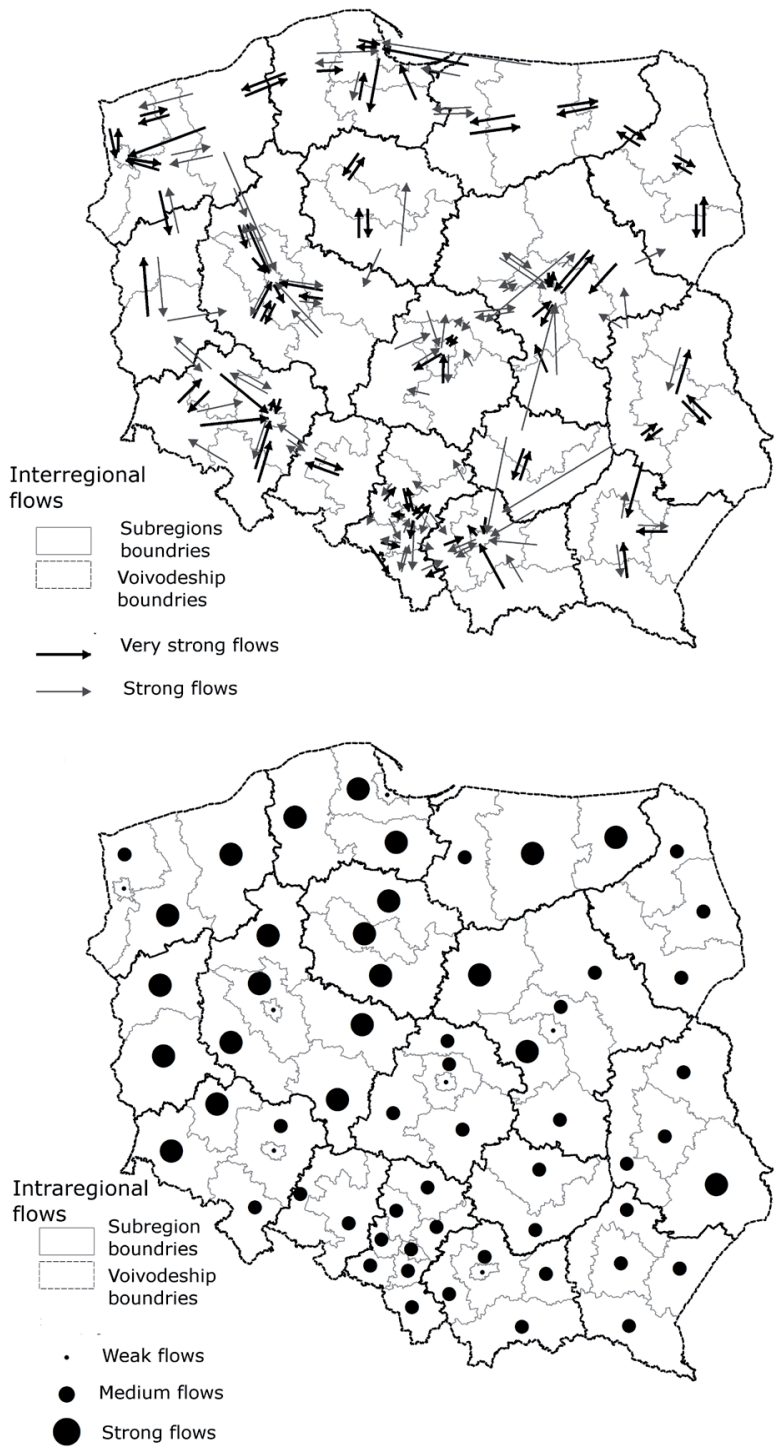

Source: Own preparation based on data BDL GUS.

9 The largest provincial cities were included in the class of weak intraregional flows. As shown by public statistics, the size of flows is recorded at the level of 0 . It results from the fact that in accordance with the methodology applied by the Main Statistical Office (GUS), migration flows within territories of cities with the district rights are not treated as migration flows since the administrational borderlines of communes are not crossed. For that reason the cities of Poznań, Łódź, Warsaw, Wrocław, Cracow and Szczecin do not display intraregional migration flows. 
Picture 3. The directions and intensity of medium migration flows between subregions.

Interregional flows

$\longrightarrow$ Medium flows ( 1 class)

$\longrightarrow$ Medium flows (2 class)

Medium flows (3 class) ।

Voivodeship boundries

Subregion boundries

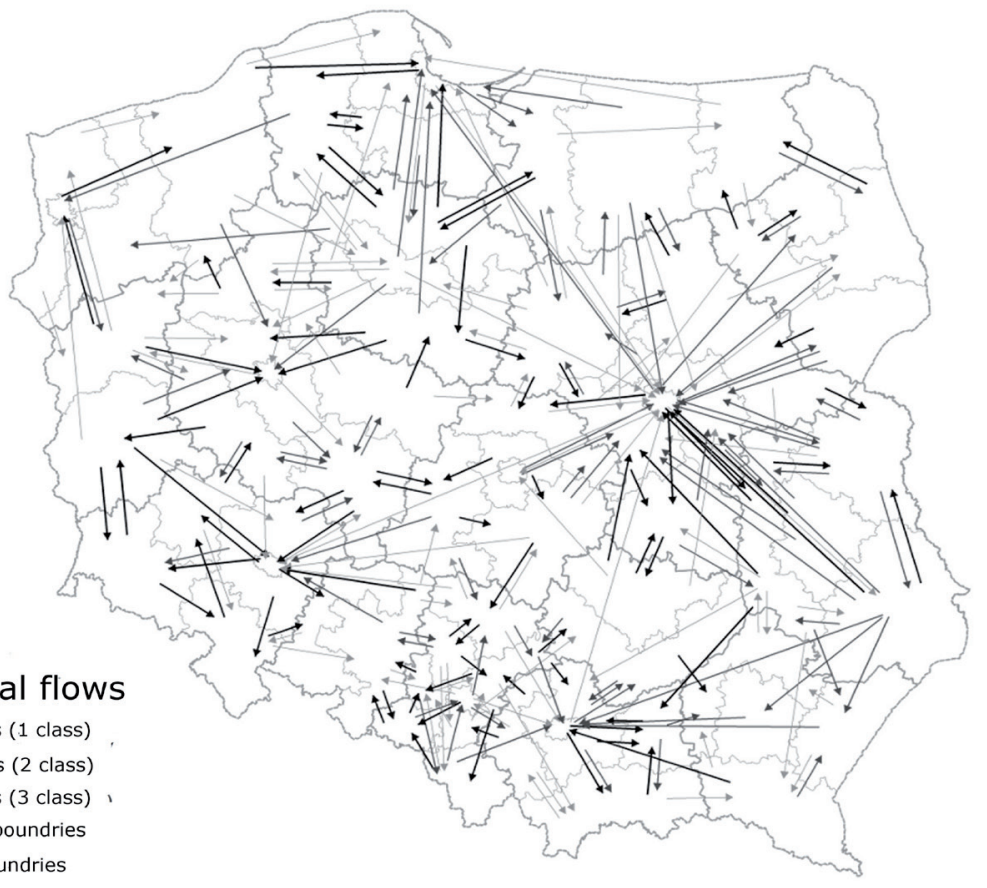

Source: Own preparation based on data BDL GUS.

Medium migration flows occurring in the Wielkopolskie region target primarily those subregions which are adjacent to the region or occur within the region. The impact of Poznan on migration flows, despite its strong economic position, is rather regional than nationwide. It must be stated, however, that Poznan functions as the core of that developing metropolitan area.

The city of Warsaw, which is Poland's largest economic centre causes bilateral migration flows between the subregions of the nearest location of the Mazowieckie region, as well as the Skierniewicki subregion of the Eódzkie region. Also, there can be seen strong one-direction flows between the subregions of the Mazowieckie region and they head towards Warsaw. Warsaw's strong position initiates inflows from the Kielecki subregion (the Świętokrzyskie region) and the Puławski subregion to the Mazowieckie region. The analysis of the migration flows of medium intensity confirms the existence of strong ties between Warsaw and other regions of the country. In addition, it confirms Warsaw's being the core of that already shaped metropolitan area. It can be stated that this area displays similar metropolitan functions to those that can be seen in well-shaped metropolitan areas of developed countries. 
The Eódzkie region has moderate intraregional flows, however, we can observe there strong interregional flows. The main target for migration flows is the city of Eódź which participates in the bilateral exchange of population with other subregions of the Eódzkie region. Also, we can observe there onedirection flows from the neighbouring subregions of the Eódzkie region to the Łódzki subregion (surrounding the city of Łódź). Strong relations holding between the Eódzkie region and the Mazowieckie region translate into intense two-direction exchange of populations of the adjacent subregions of these two regions.

The analysis of migration flows of medium strength conducted for the Eódzkie region also shows some interesting dependencies. The flows between the subregions of the region are evident. However, flows of medium strength move from the city of Eódź to the city of Warsaw and the Warszawski zachodni subregion, from the Piotrkowski subregion to the Warszawski wschodni subregion, from the Sieradzki to the Częstochowski subregion, from the Sieradzki subregion to the city of Wrocław, from the Kielecki subregion to the city of Łódź, from the Piotrkowski subregion to the city of Wrocław and the Częstochowski subregion, and from the Częstochowski subregion to the Sieradzki and Piotrkowski subregions. Due to its economic position and the intensity of migration flows, the city of Eódź can be deemed the core city of this developing metropolitan area of the Eódzkie region.

The Kielecki subregion is the most active in migration processes throughout the Świętokrzyskie region. Apart from the bilateral exchange of population with the adjacent Sandomiersko-jędrzejowski subregion, we can see strong outflows from the kielecki subregion to two subregions of the neighbouring regions, i.e., to the cities of Warsaw and Cracow. This shows a weak ability of attracting migration flows by the subregions of the Swiętokrzyskie region.

In the case of the Świętokrzyskie region the bilateral migration flows between the Kielecki subregion and the Radomski subregion are of medium strength. Moreover, other flows that were noted moved from the Kielecki subregion to the Warszawski zachodni subregion, from the Sosnowiecki subregion to the Sandomiersko-jędrzejowski subregion, and from the Sandomiersko-jędrzejowski subregion to the Tarnobrzeski and Krakowski subregions. The weak socio-economic situation of the major city (Kielce) and other parts of the region indicates the lack of possibilities of creating the metropolitan area. 


\section{CONCLUSIONS}

The article presents the analysis of the social and economic situation of subregions situated in central Poland based on the data from 2008. Also, it commented on the migration flows with their participation in the period 2008-2010. Considering the economic importance of those subregions for the national economy and the migration flows, an attempt was made to define those subregions that pretend to metropolitan areas.

Warsaw's strong economic position and its powerful impact cannot be compared to any other subregion of central Poland. Undoubtedly, Warsaw is a completely shaped metropolitan area impacting the whole country. Despite the downward trend in the economic cycle, the economic situation of Warsaw and its range of impact have remained the strongest in the country. This proves its established position and its role of the major metropolitan centre in Poland.

Taking into consideration the economic situation, as well as the strength and range of spatial dependence, the following can be recognized as metropolitan areas: the city of Poznań, the city of Łódź and the Bydgosko-toruński subregion. These subregions, however, do not play as significant role in Poland's migration flows as the city of Warsaw. Migration flows related to them are significant but they mainly demonstrate regional importance.

\section{BIBLIOGRAPHY}

Bal-Domańska B., Wilk J., Gospodarcze aspekty zrównoważonego rozwoju województw - wielowymiarowa analiza porównawcza, „Przegląd Statystyczny”, Vol. 58, No. 3-4/2011.

Biczkowski M., Muszyńska M., Müller-Frączek I., Pietrzak M.B., Wilk J., The delimitation of bipolar metropolitan area within the kujawsko-pomorskie region, „Oeconomia Copernicana", Vol. 5, No. 2/2014.

Gawryszewski A., Korcelli P., Nowosielska E., Funkcje metropolitalne Warszawy, IGiPZ PAN, Warszawa 1998.

Gorzelak G., Jałowiecki B., Europejskie granice - jednośc czy podziat kontynentu?, „Studia Regionalne i Lokalne", No. 2-3/2001.

Gorzelak G., Smętkowski M., Metropolia i jej region w gospodarce informacyjnej, Wydawnictwo Naukowe Scholar, Warszawa 2005.

Gorzelak G., Tucholska A. (ed.), Rozwoój, region, przestrzeń, MRR-Euroreg, Warszawa 2007.

Grabiński T., Wydymus S., Zeliaś A., Metody taksonomii numerycznej w modelowaniu zjarwisk spoteczno-gospodarczych, PWN, Warszawa 1989. 
Heffner K., Funkcje metropolitalne stolic województw Polski zachodniej, ekspertyza, Politechnika Opolska, UE w Katowicach, Opole 2011.

Hellwig Z., Zastosowanie metody taksonomicznej do typologicznego podziatu krajów ze względu na poziom rozwoju oraz zasoby $i$ strukture wykwalifikowanych kadr, „Przegląd Statystyczny", No. 4/1968.

Hołuj D., Hołuj A., Miasta metropolitalne jako bieguny rozwoju w gospodarce postindustrialnej, „Zeszyty Naukowe” WSE w Bochni, Vol. 4/2006.

Jałowiecki B., Globalny świat metropolii, Wydawnictwo Naukowe Scholar, Warszawa 2007.

Jałowiecki B., Metropolie, Wydawnictwo WSFiZ w Białymstoku, Białystok 1999.

Jałowiecki B., Spoteczna przestrzeń metropolii, Wydawnictwo Scholar, Warszawa 2000.

Jałowiecki B., Zarzadzanie rozwojem aglomeracji miejskich, Wydawnictwo WSFiZ w Białymstoku, Białystok 2002.

Kołodziejski J. (ed.), Koncepcja polityki przestrzennego zagospodarowania kraju, RCSS, Warszawa 2001.

Korcelli P., Aglomeracje miejskie w systemach osadniczych. Wybrane hipotezy i perspektywy badawcze, „Przegląd Geograficzny”, Vol. 48/1976.

Korcelli-Olejniczak E., Berlin and Warsaw: in search of a new role in the European urban system, „Journal of Housing and the Built Environment”, Vol. 22, No. 1/2007, http://dx.doi.org/10.1007/s10901-006-9066-1.

Ładysz I., Konkurencyjność obszarów metropolitalnych w Polsce (na przyktadzie wroctawskiego obszaru metropolitalnego), CeDeWu, Warszawa 2009.

Maik W., Podstawy geografii miast, Wydawnictwo UMK, Torun 1997.

Maik W., Pojęcie metropolii i problem badania funkcji metropolitalnych, [in:] Jażdżewska I. (ed.), Funkcje metropolitalne $i$ ich rola w organizacji przestrzeni, KGMiT UE, ŁTN Łódź 2003.

Markowski T., Marszał T., Metropolie, obszary metropolitalne, metropolizacja. Problemy $i$ pojęcia podstawowe, PAN, Komitet Przestrzennego Zagospodarowania Kraju, Warszawa 2006.

Matusik S., Pietrzak M.B., Wilk J., Ekonomiczne-spoteczne uwarunkowania migracji werwnętrznych w Polsce w świetle metody drzew klasyfikacyjnych, „Studia Demograficzne", No. 2(162)/ 2012.

Müller-Frączek I., Pietrzak M.B., Analiza porównawcza rozwoju ekonomicznego województwa kujawsko-pomorskiego w latach 2003 i 2007 z wykorzystaniem narzędzi statystyki przestrzennej, „Acta Universitatis Nicolai Copernici. Ekonomia” Vol. 39/2009.

Müller-Frączek I., Pietrzak M.B., Potencjat ekonomiczny jako miara spoteczno-ekonomicznego rozwoju regionu na przyktadzie województwa kujawsko-pomorskiego, „Acta Universitatis Nicolai Copernici. Ekonomia” Vol. 40/2009.

Müller-Frączek I., Pietrzak M.B., Wykorzystanie narzędzi statystyki przestrzennej do identyfikacji kluczowych ośrodków rozwoju województwa Kujawsko-Pomorskiego, „Acta Universitatis Nicolai Copernici. Ekonomia” Vol. 38/2008.

Nowak E., Metody taksonomiczne w klasyfikacji obiektów gospodarczych, PWE, Warszawa 1990. 
Parysek J., Metropolie: metropolitalne funkcje i struktury przestrzenne, [in:] Jażdżewska I. (ed.), Funkcje metropolitalne $i$ ich rola w organizacji przestrzeni, Wydawnictwo U乇, Łódź 2003.

Pietrzak M.B, Wilk J,. Kossowski T., Bivand R. (2014), The identification of spatial dependence in the analysis of regional economic development - join-count test application, [in:] Papież M., Śmiech S. (ed.), Proceedings of the $8^{T H}$ Professor Aleksander Zelias International Conference on Modelling and Forecasting of Socio-Economic Phenomena, 2014.

Pietrzak M.B, Wilk J., Siekaniec M., The impact of metropolitan areas on internal migrations in Poland. The case of southern regions, [in:] Papież M., Śmiech S. (ed.), Proceedings of the $7^{T H}$ Professor Aleksander Zelias International Conference on Modelling and Forecasting of Socio-Economic Phenomena, 2013.

Pietrzak M.B., Drzewoszewska N., Wilk J., The analysis of interregional migrations in Poland in the period of 2004-2010 using panel gravity model, „Dynamic Econometric Models", Vol. 12/2012, http://dx.doi.org/10.12775/DEM.2012.008.

Pietrzak M.B., Wilk J., Chrzanowska M., Economic situation of eastern Poland and population migration movement, „Metody ilościowe w badaniach ekonomicznych”, Vol. XIV, No 2/2013.

Pietrzak M.B., Wilk J., Matusik S., Gravity model as a tool for internal migration analysis in Poland in 2004-2010, [in:] Pociecha J. (ed.), Quantitative Methods for Modelling and Forecasting Economic Processes, Wydawnictwo UE w Krakowie, Kraków 2013.

Pietrzak M.B., Wilk J., Obszary metropolitalne Polski potudniowej a ruch migracyjny ludności, „Ekonomia i Prawo”, Vol. XII, No. 3/2013.

Pietrzak M.B., Wilk J., Odlegtość ekonomiczna w modelowaniu zjawisk przestrzennych z wykorzystaniem modelu grawitacji, [in:] Jajuga K., Walesiak M. (ed.), Taksonomia 22. Klasyfikacja i analiza danych - teoria i zastosowania, PN UE we Wrocławiu, Wrocław 2014.

Pietrzak M.B., Żurek M., Matusik S., Wilk J., Application of Structural Equation Modeling for analysing internal migration phenomena in Poland, „Przegląd Statystyczny”, No. 4/2012, R. LIX.

Smętkowski M., Jałowiecki B., Gorzelak G., Obszary metropolitalne w Polsce: problemy rozwojowe i delimitacja, „Raporty i analizy Euroreg”, CESRiL Euroreg, Warszawa 2009.

Strahl D. (ed.), Metody oceny rozwoju regionalnego, Wydawnictwo AE we Wrocławiu, Wrocław 2006.

Wilk J., Pietrzak M., Matusik S., Sytuacja spoteczno-gospodarcza jako determinanta migracji wewnętrznych w Polsce, [in:] Jajuga K., Walesiak M. (ed.), Taksonomia 20-21. Klasyfikacja $i$ analiza danych - teoria $i$ zastosowania, PN UE we Wrocławiu, Wrocław 2013.

Wilk J., Pietrzak M.B., Analiza migracji wewnętrznych w kontekście aspektów spoteczno-gospodarczych - podejście dwuetapowe, „Ekonometria” Vol. 2(40)/2013. 